"The emergency measures may not heal the divisions that were created during the last crisis, but might help prevent them from getting worse."

\title{
Did the EU's Crisis Response Meet the Moment?
}

\author{
ERIK JONES
}

$\mathrm{T}$ he European Union responded more quickly and decisively to the economic crisis created by the novel coronavirus pandemic than it did to the global economic and financial crisis that unfolded a decade earlier. Although there were some hiccups early on, in late February and early March 2020, Europe's leaders pulled themselves together to roll out a series of impressive monetary and fiscal packages. These policies not only helped to mitigate the economic damage from the pandemic, but also focused much-needed attention on the requirements for a sustainable recovery.

Unfortunately, responding to the initial crisis was the easy part. Maintaining an effective response is going to be harder, and so will bringing European monetary and fiscal policies back to something closer to normal. This harsh reality should not detract from the EU's accomplishments. Europe's economy would be in a worse state without the decisiveness it mustered, and Europeans in all 27 EU member states would be suffering more dramatically. Europe's leaders showed tremendous solidarity, often in the face of powerful opposition. The challenge lies in making that willingness to cooperate last. The danger is that cooperation will turn to conflict.

\section{CONTROVERSIAL MEASURES}

If European policymakers hesitated at the start of the crisis, they did so out of uncertainty about the nature of the pandemic. Other parts of the world had close experience with epidemics over the past two decades, but Europeans were largely

ERIK JONES is a professor of European studies and international political economy and director of European and Eurasian studies at Johns Hopkins University's School of Advanced International Studies. spared. As a result, European policymakers were slow to appreciate the implications of the novel coronavirus either for public health or for economic performance. Once it became clear that they faced a pandemic, European political leaders swung into action-locking down their societies, restricting cross-border movement, and reinforcing their national health systems. Not all European governments agreed on how best to respond to the pandemic, but they recognized that efforts to safeguard public health with lockdowns would shock their economies.

The first round of emergency measures was set by the middle of March. The European Commission, the EU's executive branch, loosened the rules to make it easier for national governments to run fiscal deficits, increase their public debts, and inject money directly into businesses and banks. Meanwhile, the governments themselves rolled out major programs to support household incomes, safeguard employment, and stabilize access to credit.

The European Central Bank (ЕСВ) did its part as well, by buying assets-mostly in the form of government bonds-to push money into the banking system, and then paying banks to lend to firms and households, expanding the "quantitative easing" measures it had developed in the previous crisis. Due to communications errors that surrounded their rollout, these monetary policies were not immediately successful. But the ЕСB recovered quickly and redoubled its efforts by creating a new "pandemic emergency" program to purchase even more sovereign debt through the end of the crisis.

This mixture of national fiscal responses and European monetary policies was only partly effective. The scale of the lockdown measures' impact on macroeconomic performance was unprecedented. An additional challenge came from the fact 
that not all national governments have the same ability to borrow money from private capital markets. The richer governments could borrow more easily and so support their firms, households, and banks more generously. This raised the prospect that the EU's internal market would pull apart as poorer member states fell ever further behind their wealthier counterparts.

Recognizing that inequality, European leaders came together to negotiate a set of new instruments that could help those governments and firms most in need. By April, they agreed on common programs worth $€ 540$ billion (roughly $\$ 600$ billion): The European Commission would provide $€ 100$ billion to backstop national employment protection and unemployment benefit schemes; the European Investment Bank would guarantee loans worth up to $€ 200$ billion for small and medium-sized enterprises; and the European Stability Mechanism (ESM) would lend up to $€ 240$ billion to governments to cover their medical and other costs related to the public health crisis.

These emergency measures were controversial, not least because of Europe's experience with the previous crisis. The debate about crosscountry inequality reignited. Member states in southern Europe remembered all too well how northern European countries bailed out their own banks and then changed the rules to make such bailouts more difficult by requiring governments to impose losses on private investors. As southern European banks got into trouble later, they had to work within that stricter framework. When investors (many of whom were ordinary citizens rather than more sophisticated financial actors) lost their money, the political and economic fallout was painful. Southern European governments found the prospect that they would be disadvantaged once again by the pandemic response doubly unacceptable.

The monetary package was also controversial. The ECB had bought government bonds in large quantities after the last crisis in order to support Europe's recovery. Some governments in northern Europe worried that these bond purchases created incentives for member states elsewhere to borrow beyond their means. Some also asserted that the ECB's actions exceeded its mandate.
Those concerns were taken up by German opponents of the euro as well, some of whom challenged the legitimacy of the ECB's bond purchases before the German constitutional court. The court delivered its ruling in early May, just weeks after the ECB's latest monetary policies were announced. The gist of the ruling was that the ЕСB may have exceeded its mandate. Part of the remedy was for the ЕСB to show that it considered the "proportionality" of its actions; the more important part was that these interventions be temporary rather than permanent.

That ruling did not focus on the ECB's response to the pandemic, but it did raise concerns that could apply to those measures as well. Although European governments-including Germany'sultimately chose to ignore the court's ruling, EU member states in northern Europe remained adamant that any monetary support measures should be temporary.

A further controversy centered on the loan facility provided by the ESM, which was created in 2012 to bail out national governments. The first two countries to receive support from the facility during the last crisis were Cyprus and Greece. Because of the way the ESM treaty was drafted, that support came with strict requirements that those governments implement fiscal austerity and welfare state reforms to ensure that they could make their repayments. Both Cyprus and Greece struggled to meet the conditions on the aid they received.

Other member states took note of their experience, particularly Italy and Spain. As a result, those governments did not want the ESM to be responsible for lending money during the pandemic. They preferred to borrow from the European Commission or some other organization. By contrast, the northern European governments worried that the Commission would not be strict enough in enforcing any conditions; they also questioned why the ESM was created if no government was willing to use it. The compromise reached in April was to have the ESM lend the money with no conditions attached, apart from the requirement that funds be spent on medical and related expenses.

The possibility of issuing common European debt stirred the biggest controversy, uniting all the others. Common debt would make it easier to 
redress inequities across EU member states. Common debt would reduce concerns that national governments would borrow more than they could repay, while strengthening Europe's fiscal response and so reducing the need for such an active monetary policy. And common debt would make it possible to finance spending at all levels of government-European, national, and regionalwithout going through the ESM.

The idea of issuing common European debt emerged during the last crisis in a debate over "Eurobonds." That debate ended abruptly in 2011 in the face of German opposition. It resurfaced again in the early weeks of the pandemic. The French, Spanish, and Italian governments were staunch advocates of common debt. Most northern European member states were opposed. This time, however, German Chancellor Angela Merkel reasoned that it was more important to hold Europe together than to support fiscal orthodoxy. Under her leadership, the German government changed its position and joined France to propose a plan.

\section{RECOVERY AND RESILIENCE}

The Franco-German proposal for a $€ 500$ billion European recovery fund, announced in early May, included provisions for common borrowing. These provisions were incorporated in the European Commission's plans for a larger, $€ 750$ billion fund. Although member states debated the eventual size of the fund, as well as how much of the money should be distributed as loans and how much should be given as grants, the principle of common borrowing stayed in place. Moreover, common borrowing necessitates new common revenue sources-meaning taxes that would accrue to the European budget, something many governments had long resisted.

The symbolism was enormous. Many compared the plan to Alexander Hamilton's late-eighteenthcentury program, as the first United States secretary of the Treasury, to nationalize the debts of the American state governments. But the reality of the European scheme is more subtle, as became clear both during the negotiations that dragged into the summer and in the final agreement that was reached on July 21.

The European recovery fund-called "Next Generation EU"-is temporary: the Commission will raise the money over the next six years and then pay it back over the thirty years that follow. The money is targeted: national governments have to draw up plans for how they will invest the funds they receive in line with broader European objectives, including those related to climate change and the digital economy. And any funding is conditional: the Commission will not only supervise how national governments use their funds, but also will check whether they are meeting requirements to consolidate their fiscal accounts and reform their welfare state institutions in ways that should strengthen their economies.

Most important, this funding is not free. The loans that make up $€ 360$ billion of the overall package must be repaid to the European Commission at rates of interest that cover the Commission's own cost of borrowing, plus a markup to pay for administrative costs. The remaining $€ 390$ billion in so-called grant money will be financed by European taxpayers. Some $€ 78.5$ billion of that money will flow through existing $\mathrm{EU}$ programs; the remainder is to be allocated to national governments according to criteria that loosely reflect the relative impact of the pandemic. This constitutes a net transfer for member states like Italy and Spain, but the figure is smaller than the headline numbers suggest, since the taxpayers in those countries will contribute to paying the money back.

Yet these subtleties should not overwhelm the sense of European solidarity symbolized by common debt. Public opinion polling shows that the program is popular not just in EU member states that stand to be net recipients, but also in those countries where people expect to make net contributions.

Next Generation EU also underscores the importance of the European budget. Before the pandemic, the focus was on whether and how to make up for the loss of the British financial contribution. The United Kingdom would complete its exit from the EU at the end of 2020. Because the UK has such a large economy, the British government had made substantial contributions to European projects. The expectation was that the other member states would increase their contributions to cover some of the gap that will arise in the next seven-year financial framework due to Brexit, but still, a sizable hole was left. With Next Generation EU, European finances look more robust.

The funding plan's added emphasis on "resilience" also matters. The European Union wants to lead in the global fight against climate change. Now it has a more ambitious plan to do 
so, with real resources to back it up. The EU also wants to strengthen its role in the digital economy. This will involve substantial investment in infrastructure as well as research and development. Again, Next Generation EU fills an important gap in available resources.

Taken together, these forward-looking initiatives should strengthen Europe's economy. They will not address all possible future shocks, but they will make progress in two areas of obvious and preexisting concern. Moreover, this progress will be a source of cohesion and convergence across member states, whereas purely national efforts would have reinforced existing differences. The emergency measures may not heal the divisions that were created during the last crisis, but might help prevent them from getting worse.

Finally, Next Generation EU renews the strength of the European Commission. During the last crisis, the Commission lost status to the more intergovernmental Council of the European Union and to the heads of state and government. The role that the Commission plays now is more central. Not only does it get to borrow on behalf of the EU,it also looks set to obtain new dedicated resources to pay back those debts. The Commission also gains greater influence over macroeconomic policy coordination and national welfare state reforms by controlling access to European money.

These changes lend institutional heft to the symbolism attached to the recovery fund. Next Generation EU may be temporary, but the expansion of the Commission's financial, analytical, and supervisory capabilities will be permanent. That makes it even more likely that European governments will turn to the Commission to help shape a response to the next crisis. Alexander Hamilton's legacy as Treasury secretary may not be an accurate comparison, but it is easy to see how Europe's response to the pandemic could turn out to be transformative for the European Union.

\section{THE SECOND WAVE}

The end of the summer of 2020 brought a second wave of the pandemic. The new surge of contagion became clear a few weeks after school started. Unlike the situation in the first wave, every country was now affected. Even those that had fared well in the early months of the crisis- like Germany or the Czech Republic_-faced rising numbers of infections.

The EU's response was to double down on its fiscal and monetary policy measures. The Commission moved first, announcing that it would extend the period of fiscal flexibility through the end of 2021 , and it would also keep the rules for government aid to firms and financial institutions relaxed until June and September 2021, respectively. National fiscal authorities moved quickly thereafter, prolonging their own measures to protect jobs, households, and firms, while extending tax deferrals and credit guarantee schemes.

The challenge confronting the European Central Bank was that its instruments were starting to look less effective. Monetary policy can push money into banks, but it cannot force firms to borrow. Faced with renewed uncertainty about the course of the pandemic, many firms worried about going deeper into debt. Banks shared those concerns and began tightening lending conditions accordingly.

This combination of reluctant borrowers and cautious lending weakened the link between monetary policy and economic activity. Hence some voices at the ECB began to advocate increasing European fiscal support, including moves to make Next Generation EU look more like a permanent facility. In the end, they agreed to recalibrate their monetary instruments only in December, once the impact of fiscal policy in terms of shoring up activity became clearer.

Still, doubts about the effectiveness of these fiscal responses started simmering. The old controversies resurfaced. Even as national health systems came under renewed stress, no country was willing to borrow from the European Stability Mechanism.

The Italian government was divided, with the largest party in the governing coalition, the populist Five Star Movement, rejecting any support from the ESM, while the second-largest member of the coalition, the mainstream center-left Democratic Party, insisted that the government should take advantage of the funds available. For its part, the Spanish government declared that borrowing from the ESM was out of the question.

Because of this reluctance, $€ 240$ billion of the original $€ 540$ billion in emergency relief remained untapped. The credit guarantees offered by the 
European Investment Bank also went largely unclaimed. As of December 1, 2020, only $€ 90$ billion of the backstop money provided by the European Commission for employment protection and unemployment assistance had been taken up by European governments.

Member states also wavered over plans to take up funds from Next Generation EU. At least part of the problem was connected with how the ECB's government bond purchases drove down national borrowing costs. By November 2020, twelve of the nineteen governments that use the euro as a common currency could issue 10-year bonds at negative yields. Spain and Portugal could borrow on the bond market at ten years for less than 0.1 percent-which is almost for free.

Those countries thus have no incentive to borrow from the European Commission. Even if the eight EU countries that still faced significant borrowing costs, including Italy, claimed their maximum allocations, the overall loan package looked likely to be closer to $€ 200$ billion than to the $€ 360$ billion on offer.

The grants are more certain to find takers. The question is how easily and effectively national governments can spend the money. The requirement is not just to have a plan for how European funding will be used, but also to make firm legal commitments by December 2023 and to complete expenditures by December 2026. Most European governments struggle to meet those kinds of deadlines with large infrastructure projects.

Consider the track record for spending EU funds allocated for structural investments. During the 2014-20 period, for example, Italy managed to spend just 40 percent of the money that it was allocated; Spain was able to spend just 35 percent. They were not alone in this struggle. France, Germany, and the Netherlands did better, but even they managed to spend only 55 percent of the money available.

European governments need to streamline their bureaucratic procedures to make greater use of the fiscal resources that the European Commission can provide. Until they do so, European fiscal policy will be less effective than it could be. This means that more of the burden of providing macroeconomic stimulus falls on the ECB.

But the ЕСВ has effectiveness problems of its own, particularly when firms are reluctant to borrow and banks are wary about lending. Worse, efforts by the ЕСВ to push more money into the economy have lowered government borrowing costs to a level that makes European stimulus programs less attractive to their intended participants. And as deficits and debts pile up while governments throw money into temporary income support measures, politicians become less eager to borrow to pay for ambitious infrastructure investment programs.

This negative spiral is constraining Europe's response to the second wave of the pandemic. There is no obvious way to fix it. Monetary policy and fiscal policy are moving ever further out of balance at the same time. Monetary authorities are holding increasing volumes of sovereign debt and other assets, and fiscal authorities are getting increasingly indebted.

The ECB put a brave face on its position at its December monetary policy meetings by adding resources to its emergency purchasing program. It lengthened the period during which it plans to buy and hold government securities and offered additional subsidies to banks to lend funds to private sector firms. Given the need to add stimulus in the face of the deepening crisis, the ЕСВ had little choice.

The effect on sovereign borrowing costs was immediate. Both Spain and Portugal issued tenyear bonds at negative yields soon after these monetary policy decisions were announced. Whatever residual inclination either government may have had to borrow from the European Commission vanished.

\section{FAULT LINES}

Meanwhile, the symbolism attached to Next Generation EU became more complicated because of the strengthened role of the European Commission and the decision to connect the recovery fund to the seven-year EU budget. The European Parliament needed to give its assent to the new arrangement as part of the ratification process. In return, legislators made demands about how-and how much-money should be spent. Many of these demands could not be met, since they would entail a renegotiation of the entire package.

One demand the Parliament was able to make without reopening the package was to fold rule-oflaw considerations into the basket of issues that the Commission would monitor when supervising access to European funds. This way, the Commission could withhold funds from governments that violate democratic norms as easily as it could withhold funds from governments for failing to consolidate their fiscal accounts, to reform their welfare 
state institutions in line with EU recommendations, or to spend EU money efficiently.

The Polish and Hungarian governments objected strongly to this rule-of-law linkage. They argued that the intention was to use Next Generation EU to attack them politically. Both center-right governments have undertaken constitutional reforms that have drawn fire in the European Parliament for undermining the checks and balances that safeguard democracy, particularly with respect to judicial independence. Both governments have also engaged in controversial battles with private media groups, which their opponents complain are attempts to restrict freedom of speech.

So far, the Polish and Hungarian governments have worked together to escape censure, underscoring their national sovereignty and alleging that European complaints about their actions are biased in favor of the political left. But such cooperation only works in the Council; once the Commission is in charge, they will be more vulnerable to outside influence.

The Dutch government took the other side of the debate. The Dutch had been the fiercest opponents of common borrowing, and they fought hard to limit the volume of grants in the European recovery fund. Ultimately, they conceded on both fronts. The rule-of-law issue became a matter of principle in the context of those concessions. If the Dutch government could not sell Next Generation EU as at least serving to uphold such core European values, then it might question whether the recovery fund was worth supporting at all. The fact that the Dutch faced national elections in March 2021 added weight to their position. The fact that Hungary is scheduled to go to the polls in 2022 created the prospect of a stalemate.

That stalemate threatened to materialize in December. The Hungarian and Polish governments could not block the adoption of rule-oflaw conditions attached to Next Generation EU, which passed through qualified majority voting, but they could hold up the EU's seven-year budget, which requires unanimous assent. When they did so, they demonstrated that not all governments view the European recovery fund as indispensable, and that some governments have different priorities.

That reality did not change when the German government finally succeeded in brokering a diplomatic solution to the conflict. The Dutch and the European Parliament got their rule-of-law conditionality, but the Hungarian government ensured that any attempt to enforce it would operate through a time-consuming procedure that would most likely extend beyond the 2022 Hungarian elections. The budget moved to the next stage in the ratification process, and Next Generation EU went along with it, but its symbolism as a transformative moment had been weakened.

Meanwhile, the European Council pushed to complete reforms to the ESM. These reforms originated before the pandemic and reflect the lessons learned from the last economic and financial crisis. The reason they were so long in the making is that they got tangled up in Italian domestic politics. When the reforms came up for debate in November 2019, the Italian government almost collapsed.

The ins and outs of the Italian domestic controversy are complicated, but the motivations are easy to understand. The reforms give the ESM greater authority to monitor national fiscal policy. They also give the ESM more power to enforce fiscal consolidation, which is a precondition for member states to qualify for precautionary assistance and to receive aid during a formal program, as well as during the period of recovery once any support program has ended. This new power added to the concerns of those in Italy who believe that the ESM directly threatens national sovereignty.

Prime Minister Giuseppe Conte struggled to corral support for ESM reform in the Italian parliament. But he evidently felt obliged to do so as a sign of good faith to his European colleagues, particularly those in northern member states who see the ESM as a crucial mechanism for reducing the risks associated with excessive debts and deficits.

The problem for Conte was that these ESM reforms reveal the extent to which the EU remains wedded to a particular view of fiscal orthodoxy despite all the pain that it caused after the last crisis. The term sheets for the reforms repeatedly insist on the importance of keeping government deficits below 3 percent and debts below 60 percent of gross domestic product. They also reiterate the goal that governments reduce any discrepancy between actual debt and this 60-percent limit by one-twentieth each year. 
Italy will come out of the pandemic crisis with a debt-to-GDP ratio greater than 160 percent. It will be difficult for the Italian government to reduce that ratio by five percentage points each year once the pandemic has passed. It is hard to imagine that it could sustain that pace of fiscal consolidation for twenty years. Now Rome will have to negotiate with the ESM as well as the Commission if it needs to be granted an exception.

Other governments will face similar problems, albeit less dramatic ones. The EU's fiscal orthodoxy makes borrowing to finance long-term investments even more unattractive for governments that already have excessive debt levels. Spain and Portugal may have no incentive to borrow their allocated funds from Next Generation EU, but they also have little incentive to replace those funds by borrowing with more traditional government debt, even at low or negative interest rates. Instead, their incentives will push them to try to avoid ESM supervision at any cost.

In Italy, these pressures led to a political crisis in January 2021. Former Prime Minister Matteo Renzi broke with the governing coalition over its unwillingness to tap the ESM and its poor planning to access Next Generation EU. This created an opening for Italian President Sergio Mattarella to invite former ЕСв President Mario Draghi to head a new government and get Italy's response to the crisis back on track. Draghi made it clear that only aggressive public investment would promote long-term success-even though that means additional public debt. As of early February, how Draghi would square that commitment with European fiscal rules-and whether or how long he would serve as prime minister-remained to be seen.

\section{IMAGINATION WANTED}

The northern European governments have displayed little appetite to change the rules for fiscal consolidation. On the contrary, they are eager to see those rules put back into place. The European Commission announced last October that it would start a review of whether to return to the old rules in March 2021. Governments will still be able to run larger deficits for the rest of the year, but they may have to build the requirements for fiscal consolidation into their 2022 budgets.

That review will take place before any money is distributed under Next Generation EU. Although the European recovery plan and the multi-annual budget are likely to be ratified without further controversy, it will take time for the Commission to approve national recovery and resilience plans and to begin issuing the debt to finance them. In the meantime, it remains unlikely that any government will turn to the ESM for assistance. Yet it is all but certain that measures to combat the second and possibly a third wave of the pandemic will have done further damage to European economic performance.

These prospects are not bright. True, they would be far worse if the EU had not reacted so decisively during the pandemic's first wave. But the fact that things could be worse is cold comfort for the millions of Europeans who are suffering from illness and economic hardship. It is also small consolation for those who have to look forward to decades of austerity. Responding to the initial crisis was the easy part. Holding Europe together through the recovery-and what comes after-will be much harder. It will also take more imagination. 